\title{
A chromogenic test to determine the procoagulant phospholipids in platelet-rich plasma and whole blood
}

Citation for published version (APA):

Wagenvoord, R. J., Hendrix, H. H., Kai, H., \& Hemker, H. C. (1994). A chromogenic test to determine the procoagulant phospholipids in platelet-rich plasma and whole blood. Thrombosis and Haemostasis, 72(4), 582-587. https://doi.org/10.1055/S-0038-1648919

Document status and date:

Published: 01/01/1994

DOI:

10.1055/S-0038-1648919

Document Version:

Publisher's PDF, also known as Version of record

\section{Please check the document version of this publication:}

- A submitted manuscript is the version of the article upon submission and before peer-review. There can be important differences between the submitted version and the official published version of record.

People interested in the research are advised to contact the author for the final version of the publication, or visit the DOI to the publisher's website.

- The final author version and the galley proof are versions of the publication after peer review.

- The final published version features the final layout of the paper including the volume, issue and page numbers.

Link to publication

\footnotetext{
General rights rights.

- You may freely distribute the URL identifying the publication in the public portal. please follow below link for the End User Agreement:

www.umlib.nl/taverne-license

Take down policy

If you believe that this document breaches copyright please contact us at:

repository@maastrichtuniversity.nl

providing details and we will investigate your claim.
}

Copyright and moral rights for the publications made accessible in the public portal are retained by the authors and/or other copyright owners and it is a condition of accessing publications that users recognise and abide by the legal requirements associated with these

- Users may download and print one copy of any publication from the public portal for the purpose of private study or research.

- You may not further distribute the material or use it for any profit-making activity or commercial gain

If the publication is distributed under the terms of Article $25 \mathrm{fa}$ of the Dutch Copyright Act, indicated by the "Taverne" license above, 


\title{
A Chromogenic Test to Determine the Procoagulant Phospholipids in Platelet-rich Plasma and Whole Blood
}

\author{
R. J. Wagenvoord, H. H. Hendrix, Hu Kai, H. C. Hemker \\ From the Department of Biochemistry, Faculty II, University of Limburg, Maastricht, The Netherlands
}

\section{Summary}

We have developed a chromogenic assay to measure the phospholipid-related procoagulant activity (PPA) in whole blood, or plateletrich plasma. The test is based upon thrombin formation from prothrombin by prothrombinase and is designed in such a way that procoagulant lipids are rate limiting for the prothrombinase activity. In the chromogenic test PPA concentrations equivalent to $0-10 \mathrm{nM}$ phospholipid vesicles containing 75\% phosphatidyl choline (PC) and $25 \%$ phosphatidyl serine (PS) can be measured.

The thrombin, which develops during the test, is measured with a chromogenic substrate. By the action of thrombin on this chromogenic substrate p-nitroaniline is liberated, which causes an increase in absorbance. Thrombin formed in the assay mixture activates the present platelets. This causes a linear increase of the velocity of thrombin generation during the test, i. e. a parabolic increase of product formation. For that reason the thrombin generation in time is characterized by two parameters, the basal PPA (PPA-B) of the original mixture and the increase in PPA due to platelet activation (PPA-A). To determine these figures the absorbency-data were fitted to parabolas. In most cases the contribution of PPA-A to the total amount of formed thrombin becomes considerable already after $30 \mathrm{~s}$.

Preliminary tests show that PPA-B activity in whole blood or platelet-rich plasma of patients with a thrombotic disorder is significantly higher than the activity of a control group of the same age.

\section{Introduction}

The role of platelets in hemostasis is complex. Traditionally adhesion and aggregation are said to cause primary hemostasis, providing a platelet plug that later is reinforced by thrombin mediated coagulation of fibrinogen. However, thrombin formation and platelet reactions are intricately interwoven, because thrombin induces platelet aggregation and activation, whereas platelets in contact with thrombin and collagen expose procoagulant phospholipids (1-4). Also the intercellular spaces in a platelet aggregate will contain stagnant plasma, enriched in factor $V$ released by the platelets. In this stagnant plasma high concentrations of activated clotting factors (e. g. thrombin) can be built up without being diluted by flow processes.

The role of procoagulant phospholipids in thrombin generation is pivotal. Thrombin is formed from prothrombin by factor $X_{a}$, and factor $X_{a}$ is formed by activation of factor $X$ with factor IX $_{\mathrm{a}}$, Both reactions are so slow as to be practically nil under physiological conditions in

Correspondence to: Dr. R. J. Wagenvoord, Department of Biochemistry, Faculty II, University of Limburg, Universiteitssingel 50, N-6229 ER Maastricht, The Netherlands - FAX Number: +31 43670988 the absence of procoagulant phospholipids (5-11). A procoagulant phospholipid surface is obligatory for physiologically significant thrombin formation. A surface will only be procoagulant when a sufficient amount of negatively charged phospholipids (mostly PS) are present (1). The outer leaflet of the membrane of a resting platelet contains hardly any PS $(1,2)$. Therefore it is hardly or not procoagulant. On activation of the platelet the PS present in the inner leaflet of the membrane will be translocated to the outer leaflet $(1-4)$. This is the so-called flip-flop reaction and by this process the platelet will become procoagulant. Platelets can be activated by the natural activators thrombin and collagen, but also by calcium ionophore A23187 (12), diamide (1) and several other compounds. Because platelets are activated by thrombin, this enzyme facilitates its own formation. This is not the only positive feedback loop in the coagulation process. The factors $\mathrm{V}_{\mathrm{a}}$ and VIII ${ }_{a}$, which are required for optimal activation of prothrombin and factor X, respectively, arise from thrombin action upon their plasmatic precursors factors $\mathrm{V}$ and VIII.

The level of activated clotting factors in whole blood usually is low, because they are scavenged by a variety of inhibitors in the plasma. Below a certain threshold these activated factors are not harmful (13). Also the amount of procoagulant phospholipids exposed in whole blood is low, because resting platelets have a mechanism that relocates PS from the outer to the inner leaflet of the membrane (14). A minor amount of the PS is probably present in the outer leaflet of the unactivated platelet, causing a residual procoagulant activity. Also procoagulant phospholipid activity (PPA) may be present in the form of microvesicles (15) and, to a limited extent, on lipoproteins (16). A high PPA activity in plasma will probably lower the threshold at which activated clotting factors will be able to start explosive thrombin generation, which, in vivo will probably be an important step in developing thrombosis. Thus the susceptibility of a person to get thrombosis may very well be correlated with the level of procoagulant activity of his blood, be it on the platelets or elsewhere.

Apart from the basal PPA activity (PPA-B) that is thought to be present in circulating blood, there is the PPA activity generated in blood by activation of the platelets as soon as the first traces of thrombin are formed. It can be imagined that this activation-related part of the PPA (PPA-A) may differ with the status of the platelets in the plasma. Simply the number of platelets may be important, but also the facility with which the "flip-flop" reaction is triggered, or the PS content. Some platelets may be more susceptible to the activating action of thrombin than others. This may be related to the membrane composition, membrane fluidity, or the presence of platelet inhibitors. It is well possible that easily triggered platelets cause a higher thrombosis risk than lazy ones. It therefore may be interesting to be able to test the excitability of a platelet. Also measuring the excitability of a platelet as a function of drugs administered to the patient, or added in vitro may serve as a screening test for potential flip-flop inhibitors. Apart from a high basal 
PPA also a rapid generation of PPA by small amounts of activated clotting factors may represent a thrombotic risk.

It seems desirable to be able to determine both PPA-A and PPA-B in blood. Because platelets are notoriously labile, it is important that this test can be carried out on whole blood or platelet-rich plasma that has undergone a minimum of ex vivo manipulations. In this article we describe such a test, To develop this test we have used the property of the prothrombinase to be critically dependent upon the presence of procoagulant phospholipids. Also the factor $\mathrm{X}$ activating complex has this property. We have chosen to use prothrombinase as an indicator of practical reasons: factor $V_{a}$ is stable, in contrast to factor VIII $_{a}$.

\section{Methods and Materials}

\section{Materials}

\$2238 and fibrinogen were purchased from AB Kabi Diagnostica, Stockholm, Sweden. Ovalbumin (grade V) and Echis carinatus venom were obtained from Sigma, The purified factor X activator from Russell's viper venom was a gift from Dr. T. Tran (then at Baxter, Düdingen, Switzerland).

All other reagents used were of the highest grade commercially available.

\section{Proteins}

Bovine factor $\mathrm{X}$ was prepared according to Fujikawa et al. (17). Factor $\mathrm{X}_{\mathrm{a}}$ was obtained by activation of factor $X$ with Russell's viper venom (18). Bovine prothrombin was purified according to Owen et al. (19). Thrombin was isolated as is described elsewhere (20). Bovine factor $V$ was isolated according to Lindhout et al. (21) and factor $\mathrm{V}_{\mathrm{a}}$ by activation of factor $\mathrm{V}$ with $2 \mathrm{nM}$ thrombin during $60 \mathrm{~min}$ at $37^{\circ} \mathrm{C}$ in the presence of $2 \mathrm{mM} \mathrm{CaCl}$. After isolation all proteins were dialyzed against $175 \mathrm{mM} \mathrm{NaCl}, 50 \mathrm{mM}$ Tris- $\mathrm{HCl}, \mathrm{pH} 7.9$ (Tris/NaCl, pH 7.9). Dilutions were made in the same buffer plus $1 \mathrm{mg} / \mathrm{ml}$ ovalbumin.

\section{Phospholipids and Phospholipid Vesicles}

PC and PS were isolated from egg-yolk and bovine brain, respectively, and purified according to Comfurius and Zwaal (22). Vesicles were prepared by 5 min sonication of a phospholipid mixture (in Tris/ $\mathrm{NaCl}, \mathrm{pH} 7.9$ ) of $75 \% \mathrm{PC}$ and $25 \%$ PS using an MSE Mark II 150-Watt ultrasonic disintegrator, set at $9 \mu$ peak to peak amplitude. Phospholipid concentrations were determined by analysis of the phosphate content (23).

\section{Blood Collection}

We have noticed that the activity of the platelets in blood depends on the way the blood is collected. When blood is collected on citrate alone the procoagulant activity increases rapidly in time and is markedly higher after $1 \mathrm{~h}$. When blood is taken on ACD ( 5 parts blood are mixed with 1 part ACD, i. e. $183 \mathrm{mM}$ glucose, $80 \mathrm{mM}$ trisodium citrate, $52 \mathrm{mM}$ citric acid), however, the procoagulant activity remains at starting level for at least a few hours.

For the above mentioned reasons it is necessary that the blood is collected on $\mathrm{ACD}$ and measured within $2 \mathrm{~h}$. If individual variation between patients has to be measured, citrated blood may be used, but in this case the procoagulant activity should be measured within $20 \mathrm{~min}$ after blood collection. The blood should be stored at room temperature and never below $10^{\circ} \mathrm{C}$, because in a number of cases we noticed some activation of the platelets when they were kept at $4^{\circ} \mathrm{C}$.

\section{Preparation of Washed Erythrocytes}

Blood $(500 \mu \mathrm{l})$ was mixed with $10 \mathrm{ml}$ isotonic salt and centrifuged at $100 \times \mathrm{g}$ during $10 \mathrm{~min}$. The supernatant was discarded and the pellet was suspended and centrifuged in the same way two times. Finally the erythrocytes were centrifuged at $1000 \times \mathrm{g}$ during $10 \mathrm{~min}$ to obtain packed cells.

\section{Execution of the PPA-test in PRP or Whole Blood}

The design of the assay is based on data described under Results. PRP or whole blood is diluted $20 \times$ in isotonic salt. To $300 \mu$ ld diluted PRP or blood is added $300 \mu \mathrm{l} 6 \mu \mathrm{M}$ prothrombin (reagent 1 ) and the mixture is preincubated at $37^{\circ} \mathrm{C}$ during $5 \mathrm{~min}$. Then $300 \mu \mathrm{l}$ of reagent 2 (prewarmed at $37^{\circ} \mathrm{C}$ ), i, e. a mixture containing $1.2 \mathrm{nM}$ factor $\mathrm{X}_{\mathrm{a}}, 1.2 \mathrm{nM}$ factor $\mathrm{V}_{\mathrm{a}}, 15 \mathrm{mM} \mathrm{CaCl}_{2}$, is added to start the reaction. At predetermined intervals, samples of $100 \mu \mathrm{l}$ are taken and mixed with $500 \mu \mathrm{l}$ stop-buffer. The stop-buffer is Tris/ $\mathrm{NaCl}+10 \mathrm{mM}$ EDTA (pH 7.9), or $100 \mathrm{mM}$ ammonium bicarbonate, $10 \mathrm{mM}$ EDTA (pH 8.0). In case of PRP both stop-buffers can be used, however, to test whole blood only the last buffer can be used, in which the erythrocytes lyse. Lysis of the erythrocytes takes less than $2 \mathrm{~min}$. Finally formed thrombin is measured by addition of $25 \mu 1$ S2238 of $2 \mathrm{mM}$. To study the effect of platelet activators or drugs on PRP or whole blood, this compound is added to the prothrombin and a 5 min preincubation step is introduced. Because the test is for use in a clinic a device for stirring the samples was not used. The platelet count was determined in the original samples (and not after dilution of the samples) with a Thrombocounter-C (Coulter Electronics, LTD, Luton, UK), or with the Hematology system of Technicon Instruments Corporation (Tarrytown, NY, USA).

\section{Results}

\section{The Chromogenic-assay for Procoagulant Phospholipids}

It is known from previous work (Rosing et al., 9) that linear thrombin formation is observed when factors $X_{a}$ and $V_{a}$ are added to a mixture containing prothrombin and phospholipids. The general procedure described at "Execution of the PPA-test in PRP or whole blood" was used to determine the optimal conditions to measure procoagulant phospholipids. We noticed that by using $2 \mu \mathrm{M}$ prothrombin in the reaction mixture, the reaction rate is not affected by the decrease of the prothrombin concentration. Maximally $0.15 \mu \mathrm{M}$ prothrombin is activated so the residual amount of prothrombin will be higher than $1.85 \mu \mathrm{M}$, which is far above the $\mathrm{K}_{\mathrm{m}}(24)$ and thus no effect on the reaction rate is expected. In search for optimal conditions it should be considered that factors $\mathrm{X}_{\mathrm{a}}$ and $\mathrm{V}_{a}$ have to be present in excess over the amount of binding sites on the phospholipid. As a model phospholipid we used vesicles containing $25 \% \mathrm{PS}$ and $75 \% \mathrm{PC}$. Such a vesicle suspension contains about $5 \mathrm{nM}$ sites for the $\mathrm{FX}_{\mathrm{a}}-\mathrm{FV}_{\mathrm{i}}$-complex per $\mu \mathrm{M}$ phospholipid (24). To determine optimal conditions to measure procoagulant phospholipids we varied the $\mathrm{FX}_{\mathrm{a}}-\mathrm{FV}_{\mathrm{a}}$-concentration from 0 to $0.8 \mathrm{nM}$ in the reaction mixture and measured the rate of thrombin formation. The rate is proportional with the $\mathrm{FX}_{\mathrm{a}}-\mathrm{FV}_{\mathrm{a}}$-concentration and is very low in the absence of phospholipids (blank). However, this blank becomes substantial when the $\mathrm{FX}_{\mathrm{a}}-\mathrm{FV}_{\mathrm{a}}$ concentration is high and phospholipids with low concentration of PS have to be measured. To compromise between a high sensitivity for procoagulant phospholipids and a low blank value we have chosen for a concentration of $0.4 \mathrm{nM} \mathrm{FX}-\mathrm{FV}_{\mathrm{a}}$ in the reaction mixture.

Fig. 1 shows that the rate of thrombin formation is linear in time (inset of Fig. 1) and that the rate of thrombin formation is proportional with the phospholipid concentration up to about $10 \mathrm{nM}$ (drawn straight line; $y=2.17 x-0.761$, in which $y$ is the rate of thrombin formation and $\mathrm{x}$ the phospholipid concentration). The rate of thrombin formation is also linear dependent on the $\mathrm{FX}_{\mathrm{a}}-\mathrm{FV}_{\mathrm{a}}$-concentration (not shown).

Fig. 2 shows that the procoagulant activity of isolated platelets can be measured in a simple way by using the described method. The platelets were isolated according to van Rijn et al. (12). The platelets then were treated with thrombin, with collagen and with thrombin + collagen. Because no $\mathrm{Ca}^{2+}$ was present during pretreatment it was not expected that the procoagulant activity arose forthwith, but only after recalcification, i. e. during the experiment. 


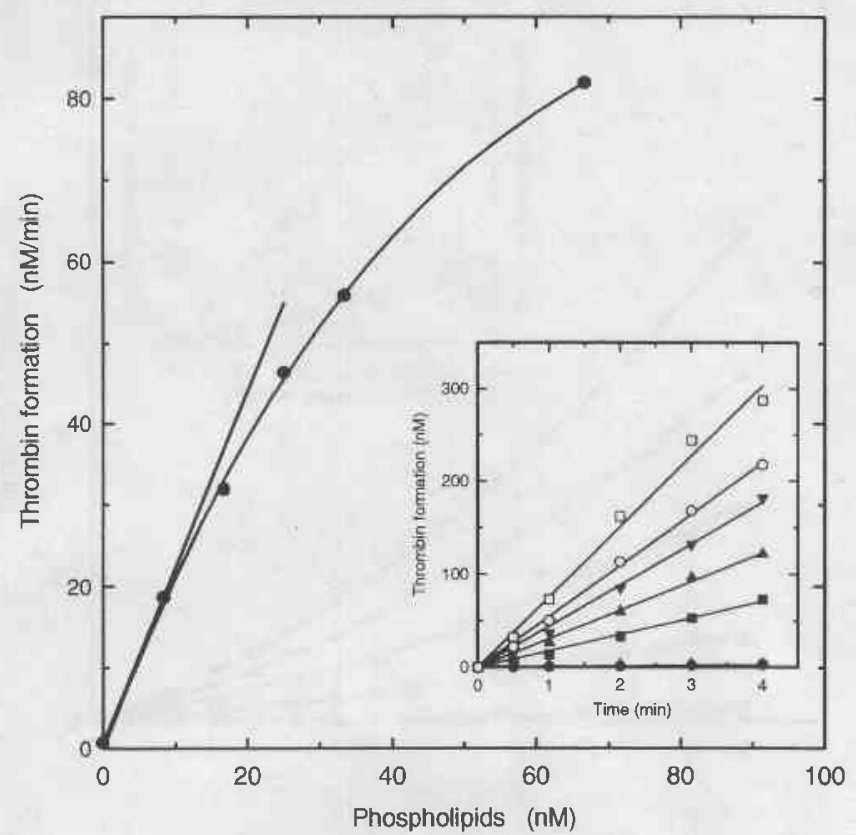

Fig. 1

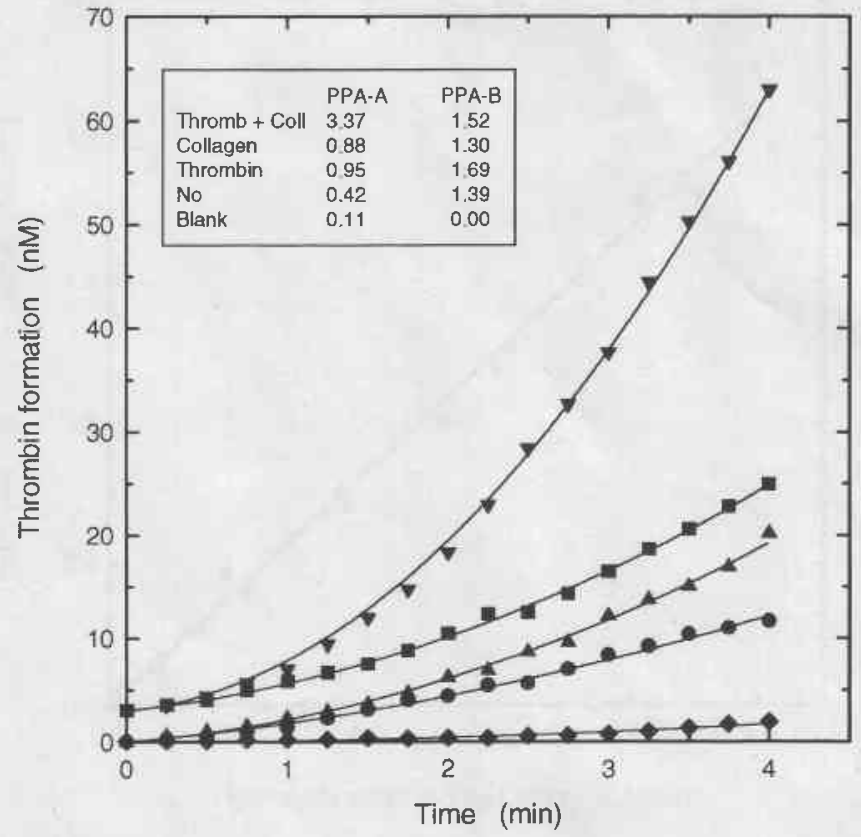

Fig. 2

Fig. I Measurement of procoagulant phospholipid vesicles. To $100 \mu \mathrm{l}$ prothrombin $(6 \mu \mathrm{M}$, in Tris-buffer, pH 7.9$)$ was added $100 \mu \mathrm{l}$ phospholipid vesicles (25\% PS; 75\% PC) diluted in isotonic salt and after $5 \mathrm{~min}$ preincubation at $37^{\circ} \mathrm{C} 100 \mu$ of $1.2 \mathrm{nM}$ factor $\mathrm{X}_{\mathrm{a}}, 1.2 \mathrm{nM}$ factor $\mathrm{V}_{\mathrm{a}}$ and $15 \mathrm{mM} \mathrm{CaCl}$ in Tris/NaCl $(\mathrm{pH} 7.9), 0.2 \%$ ovalbumin $\left(\mathrm{FX}_{\mathrm{a}}-\mathrm{FV}_{\mathrm{a}}-\mathrm{Ca}\right.$-mixture). The phospholipid concentration in the reaction vessel is indicated in the figure. Samples of $100 \mu \mathrm{l}$ were taken at $0.5,1,2,3$ and $4 \mathrm{~min}$ and mixed with $500 \mu 110 \mathrm{mM}$ EDTA + Tris/NaCl to stop the prothrombinase. Formed thrombin was measured by addition of $25 \mu 1 \mathrm{~S} 2238$ $(2 \mathrm{mM})$. In the inset the amount of formed thrombin is plotted against the time. The phospholipid concentration was $0(-\mathbf{O}-), 8.3(-\mathbf{-}-)$, $16.7(-\mathbf{A}-), 25(-\nabla-)$, 33.3 (-O-) and 66.7 (- $\square-) \mathrm{nM}$. The slopes in the inset were plotted in the figure

Fig. 2 Procoagulant activity of isolated platelets, Platelets $(600 \mu \mathrm{l})$ were incubated with either $600 \mu \mathrm{l} 6 \mu \mathrm{M}$ prothrombin $(-\mathbf{0}-)$, $600 \mu \mathrm{l} 6 \mu \mathrm{M}$ prothrombin $+10 \mu \mathrm{g} / \mathrm{ml}$ collagen $(-\mathbf{A}-), 600 \mu \mathrm{l} 6 \mu \mathrm{M}$ prothrombin $+9 \mathrm{nM}$ thrombin $(-\boldsymbol{\omega}-)$, or $600 \mu \mathrm{l} 6 \mu \mathrm{M}$ prothrombin $+10 \mu \mathrm{g} / \mathrm{ml}$ collagen $+9 \mathrm{nM}$ thrombin $(-\mathbf{\nabla}$-) during $5 \mathrm{~min}$ at $37^{\circ} \mathrm{C}$. The blank (no platelets) is represented by $\left(-\right.$-). To start the prothrombinase $600 \mu 1 \mathrm{FX}_{\mathrm{a}}$-FV -Ca-mixture (see Fig. 1) was added. The platelet concentration in the reaction vessel was $4.2 \times 10^{9}$ platelets/l, Samples of $100 \mathrm{ml}$ were taken each $15 \mathrm{sec}$ and measured as described in Fig. 1. The symbols in the figure are the actually measured amounts of formed thrombin, whereas the drawn lines are parabolas with the formula $\mathrm{T}=\mathrm{at} \mathrm{t}^{2}+\mathrm{bt}+\mathrm{c}$, in which $\mathrm{T}$ is the amount of thrombin, $\mathrm{a}, \mathrm{b}$ and $\mathrm{c}$ are constants and $\mathrm{t}$ is the reaction time. The constants were determined by curve fitting; $\mathrm{c}$ was set to 0 when no thrombin was present during the preincubation and to 3 when thrombin was present during preincubation. The constants are given in the inset; PPA-A $=a$ and PPA-b $=b$. No corrections were made for the blank

The first phenomenon that meets the eye is that the rate of thrombin formation initially is low, but not zero, and that the velocity is building up in time with a constant first derivative. To analyze the data in Fig. 2 we have fitted them to parabolas. In this way we found the constants for the formula $\mathrm{T}=\mathrm{at}{ }^{2}+\mathrm{bt}+\mathrm{c}$, which were used to draw the curves in the figure. When no thrombin is added during pretreatment of the platelets the curves pass through the origin, $\mathrm{c}=0$, but when the platelets were pretreated with thrombin, $3 \mathrm{nM}$ thrombin is present at $\mathrm{t}=0$ and thus $\mathrm{c}=3$. The constant $\mathrm{b}$ is the linear part of the thrombin generation, present from zero=time on, i. e. the basal activity (PPA-B), whereas the constant $\mathrm{a}$ is proportional to the linear increase of the prothrombinase in the mixture, i. e. PPA-A. Fig. 2 shows that the PPA-B is hardly influenced by the pretreatment of the platelets, however, the acceleration (PPA-A) depends on the pretreatment, Pretreatment with $4.5 \mathrm{nM}$ thrombin, or $10 \mu \mathrm{g} / \mathrm{ml}$ collagen has a minor stimulating effect on the acceleration, whereas thrombin plus collagen has a much more pronounced effect.

We have measured the activity of untreated platelets as function of the concentration. Samples were prepared with $0-50 \times 10^{9}$ platelets $/ 1$, and tested as descibed in Fig. 2. The result is shown in Fig. 3. It is noted that the procoagulant activity is linearly dependent on the number of the platelets. For this reason it is allowed to compare samples with different platelet concentrations provided that the found activities are expressed as activity per number of platelets.

These results show that the procoagulant activity of phospholipids and the activity that develops in patelets during the test can be measured in a routine test. However, the isolation of platelets requires a few hours, may induce activation and thus is not suitable for clinical and/or epidemiological purposes. For that reason we investigated whether the procoagulant activity of whole blood could be measured. We noticed that erythrocytes disturb the thrombin determination, because they settle in the cuvette during the measurement. To avoid this source of error we removed the cells either by centrifugation or by lyses in ammonium bicarbonate. In this way thrombin can be well measured provided that the final blood dilution at least is $60 \times$ in order to avoid too high background absorption by haemoglobin. Fig. 4 shows that lyses, executed in this way, and centrifugation of the erythrocytes give comparable results. However, the amidolytic activity of thrombin in ammonium bicarbonate buffer is about $80 \%$ of that in $175 \mathrm{mM} \mathrm{NaCl}, 50 \mathrm{mM}$ Tris- $\mathrm{HCl}(\mathrm{pH} 7.9)$ due to an effect of the salt present (25).

We also have noticed that the erythrocytes do account for a considerable amount of the basal activity (see Table 1). This activity is not 


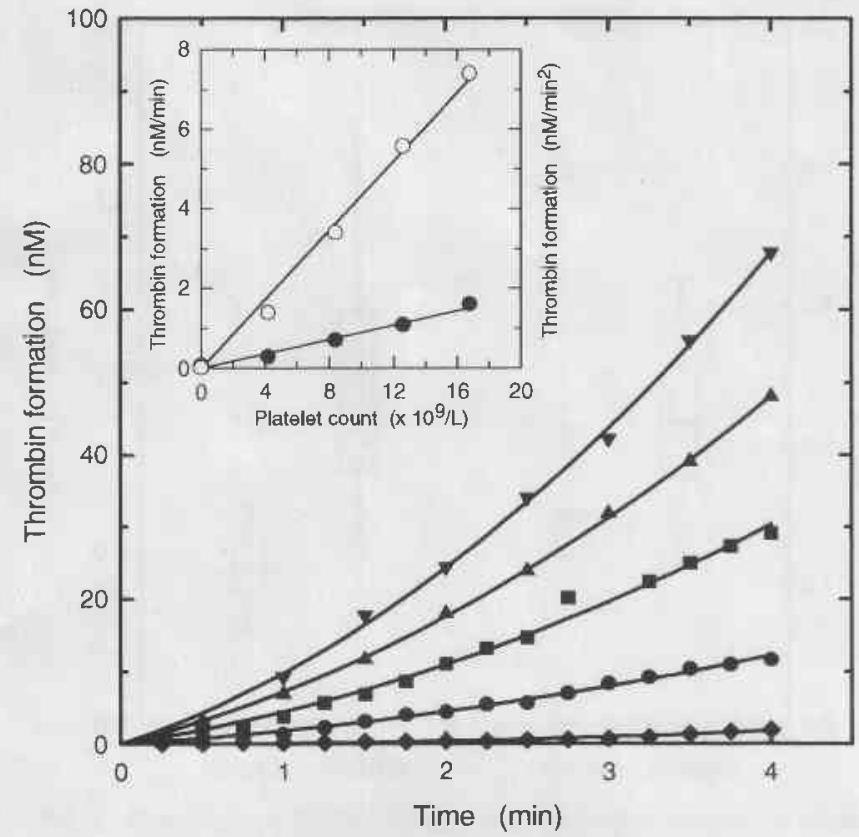

Fig. 3

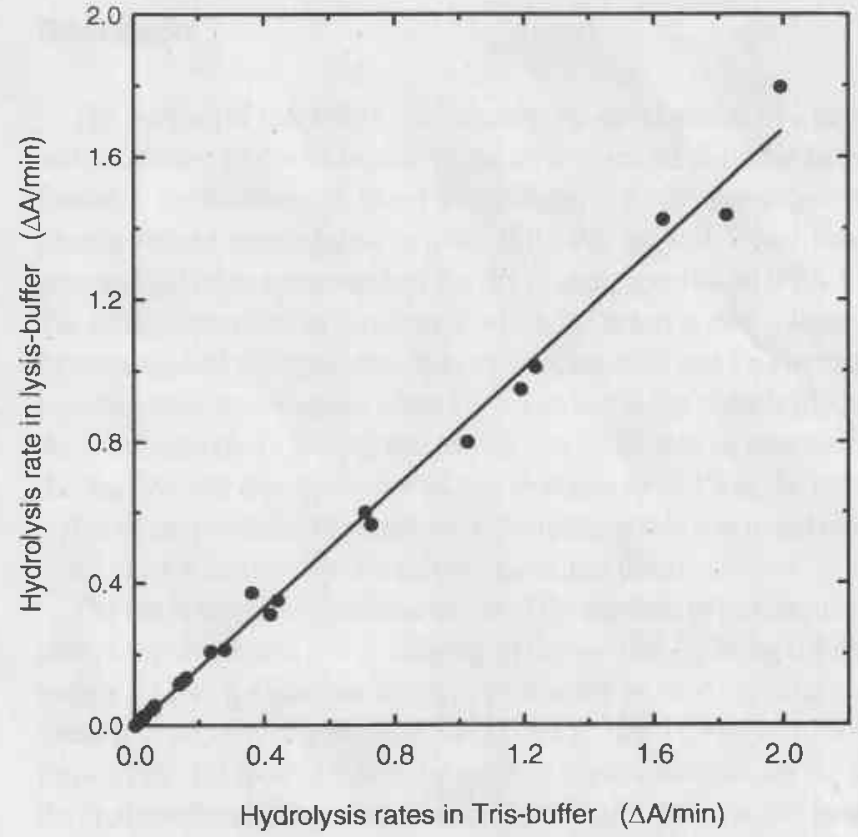

Fig. 4

Fig. 3 The procoagulant activity as function of the platelet concentration. The procedure described in Fig. 2 was used. However, samples were prepared with $0(--), 12.5(-\mathbf{-}), 25(-\mathbf{-}-), 37.5(-\mathbf{A}-)$ and $50(-\nabla-) \times 10^{9}$ cells/l. Because the sample is one third of the reaction volume the concentration of the platelets in the reaction mixture is $0-16.7 \times 10^{9}$ cells $/$. The data were fitted to parabolas as described in Fig. 2. In this way we found the PPA-A and PPA-B for each platelet concentration. These data were plotted in the inset. The open circles (-O-) give the results for PPA-B and closed circles (-O-) for PPA-A

Fig. 4 Assessment of procoagulant phospholipids in whole blood. Several blood samples were collected in $3.8 \%$ sodium citrate (1 part citrate, nine parts blood). Blood was diluted 20 times in isotonic salt and then the phospholipid related activity was measured as in Fig. 1. The reaction was stopped by sub-sampling in $500 \mu \mathrm{l}$ of either Tris/ $\mathrm{NaCl}+10 \mathrm{mM}$ EDTA (pH 7.9), or $100 \mathrm{mM}$ ammonium bicarbonate, $10 \mathrm{mM}$ EDTA (pH 8.0). In case of sub-sampling in Tris/NaCl-EDTA the red cells were spun down and thrombin was measured in the supernatant. In the second case the centrifuge-step was omitted and thrombin was after 2 min to allow complete lysis of the erythrocytes. The hydrolysis rate in Tris-buffer is given on the x-axis and the hydrolysis rate in ammonium bicarbonate buffer (lyse buffer) is given on the $y$-axis

stimulated by thrombin, collagen, or thrombin plus collagen, which means that the PPA-A of washed erythrocytes is close to zero and that thrombin formation is linear in time.

When PPA is measured in PRP it is not necessary to use the ammonium bicarbonate stop-buffer, but Tris/ $\mathrm{NaCl}$ stop-buffer can be used also. After stopping the reaction with EDTA it is necessary to measure the formed thrombin within a few minutes, because the present ATIII inactivates the thrombin at a rate of approximately $0.5 \%$ per min.

Both the factor $V$ released from platelets during activation $(26,27)$, and the plasma factor $V$ might affect the assay. To study the effect of factor $V$ on this assay we have added factor $V$ to samples with a low concentration of procoagulant phospholipids and performed the assay

Table I Phospholipid related activity in whole blood and washed erythrocytes. Blood from two healthy volunteers was collected on ACD. Part of the blood was used to prepare washed erythrocytes (packed cells). The whole blood was diluted $20 \times$ and the packed cells $50 \times$ in isotonic salt. Then the PPA was determined. The values for the erythrocytes were corrected for the hematocrit (HCT) of the blood, i. e. $\times$ HCT/0.40. The diluted blood/erythrocytes was incubated during 5 min at $37^{\circ} \mathrm{C}$ with $3 \mu \mathrm{M}$ prothrombin (i), with $3 \mu \mathrm{M}$ prothrombin $+5 \mu \mathrm{g} / \mathrm{ml}$ collagen (ii), with $3 \mu \mathrm{M}$ prothrombin $+4.5 \mathrm{nM}$ thrombin (iii), or with $3 \mu \mathrm{M}$ prothrombin $+5 \mu \mathrm{g} /$ collagen $+4.5 \mathrm{nM}$ thrombin (iv). The data were corrected for thrombin formation in the absence of blood/erythrocytes

\begin{tabular}{|c|c|c|c|c|c|}
\hline \multirow[t]{2}{*}{ Exp. } & \multirow[t]{2}{*}{ Pretreatment } & \multicolumn{2}{|l|}{ Whole blood } & \multicolumn{2}{|c|}{ Washed erythrocytes } \\
\hline & & $\begin{array}{l}\mathrm{PPA}-\mathrm{A} \\
\left(\mathrm{nM} / \mathrm{min}^{2}\right)\end{array}$ & $\begin{array}{l}\text { PPA-B } \\
(\mathrm{nM} / \mathrm{min})\end{array}$ & $\begin{array}{l}\text { PPA-A } \\
\left(\mathrm{nM} / \min ^{2}\right)\end{array}$ & $\begin{array}{l}\text { PPA-B } \\
(\mathrm{nM} / \mathrm{min})\end{array}$ \\
\hline \multirow[t]{4}{*}{1} & (i) no & 0.0 & 0.120 & 0.0 & 0.177 \\
\hline & (ii) collagen & 0.043 & 0.110 & 0.017 & 0.172 \\
\hline & (iii) thrombin & 0.075 & 0.098 & 0.019 & 0.147 \\
\hline & (iv) coll + thromb & 0.281 & 0.095 & 0.0 & 0.193 \\
\hline \multirow[t]{4}{*}{2} & (i) no & 0,126 & 0.410 & 0.007 & 0.152 \\
\hline & (ii) collagen & 0.095 & 0.396 & 0.027 & 0.081 \\
\hline & (iii) thrombin & 0.292 & 0.328 & 0.0 & 0.184 \\
\hline & (iv) coll + thromb & 0.659 & 0.556 & 0.007 & 0.109 \\
\hline
\end{tabular}




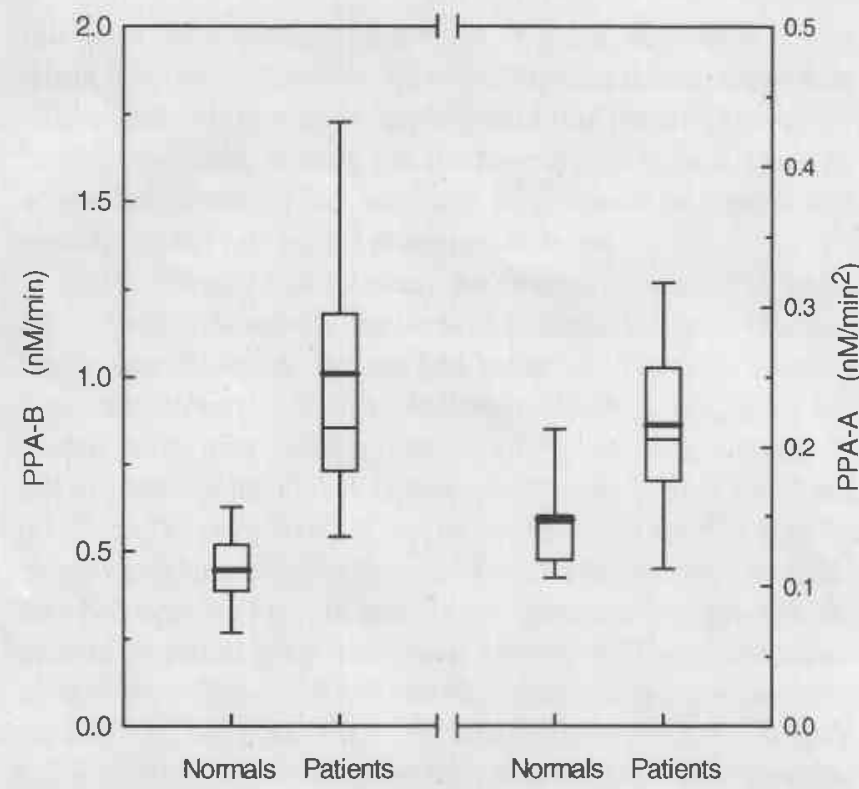

Fig, 5 Determination of PPA in whole blood of normals and patients treated for thrombotic disease with sintromitis. In all cases the blood was collected on ACD. The PPA-A and PPA-B were determined as in Fig. 2, however, samples were taken each $30 \mathrm{sec}$. In the left part of the figure the values for PPA-B of normals (11 cases) and patients ( 9 cases) are plotted in vertical box plots, which gives the mean (thick line) of the PPA-B values, the $95 \%$ and $5 \%$ percentile values (captions). the $75 \%$ and $25 \%$ percentile values (box) and the $50 \%$ percentile value (thin line. which sometimes falls under the thick line). In the right part of the figure the values for PPA-A of normals and patients are plotted in box plots. The age of both the normals and patients was between 50 and 70 years

Table 2 The effect of FV on the platelet assay. Samples were prepared with phospholipid vesicles (75\% PC; $25 \%$ PS) and variable amounts of factor $\mathrm{V}$. The assay was done as described in Fig. 2. The phospholipid concentration in the reaction mixture was $1.67 \mathrm{nM}$

\begin{tabular}{lll}
\hline $\begin{array}{l}\mathrm{FV} \\
(\mathrm{nM})\end{array}$ & $\begin{array}{l}\mathrm{PPA}-\mathrm{A} \\
\left(\mathrm{nM} / \mathrm{min}^{2}\right)\end{array}$ & $\begin{array}{l}\mathrm{PPA}-\mathrm{B} \\
(\mathrm{nM} / \mathrm{min})\end{array}$ \\
\hline 0 & 0.17 & 1.81 \\
0.2 & 0.21 & 1.73 \\
0.4 & 0.24 & 1.78 \\
0.6 & 0.30 & 1.74 \\
0.8 & 0.38 & 1.88 \\
\hline
\end{tabular}

as described in Fig. 2. Then the PPA-A and PPA-B was determined by curve fitting. The results are given in Table 2 . One can notice that the basal activity is not affected by factor $\mathrm{V}$, however, the PPA-A increases from 0.17 to 0.38 by increasing the factor $V$ concentration from 0 to $0.8 \mathrm{nM}$.

\section{Normal Values and Some Preliminary Data on Patient Samples}

We did a preliminary experiment to test the usefulness of the test as a routine assay. We measured the activity of a small group of normals and of a group of patients a previous (more than 6 months ago) myocardial infarction, which for that reason were treated with sintromitis at the Thrombosis Service of the Academic Hospital of Maastricht. In Fig. 5 it is seen that the PPA-B activity of whole blood is higher in this group than in a group of age matched healthy volunteers.

\section{Discussion}

The purpose of this article is to describe the development of a rapid and simple test to determine one of the three essential thrombin based feedback mechanisms of blood coagulation, i. e. the generation of platelet related procoagulant activity (PPA-A), as well as the basal phospholipid related procoagulant activity of untriggered blood (PPA-B). The PPA is measured in a system in which the reaction rate is limited by procoagulant phospholipids. It is well documented that a membrane becomes more procoagulant when PS is exposed in the outer leaflet of the membrane $(1-4)$, for that reason it is very likely that an increase of the reaction rate during the test is due to exposure of PS in the outer leaflet of the platelets. The increase of the reaction rate was found only in the cases when the reaction mixture contained platelets.

The test is essentially a measurement of the amounts of procoagulant phospholipids present and developing in the sample. By using $0.4 \mathrm{nM}$ factors $X_{a}$ and $V_{a}$ (final concentration) the assay is very sensitive and linear in procoagulant phospholipids (25\% PS, $75 \%$ PC) up to $10 \mathrm{nM}$. Rosing et al. (9) showed that in the absence of phospholipids the $K_{m}$ of the prothrombinase for prothrombin is about $35 \mu \mathrm{M}$, whereas this number decreases to $32 \mathrm{nM}$ in the presence of $2.6 \mu \mathrm{M}$ phospholipids. This means that by using $2 \mu \mathrm{M}$ prothrombin the formed $\mathrm{FX}_{\mathrm{a}}-\mathrm{FV}_{\mathrm{a}}$-PL-complex is completely saturated with prothrombin and thus thrombin formation is not limited by prothrombin. To make the test as simple and sensitive as possible reagents 1 and 2 (see "Execution of the PPA-test in PRP or whole blood") were prepared with compositions based on the results obtained in Fig. 1.

With the reagents 1 and 2 tests were done with both isolated platelets, whole blood and PRP. In Fig. 2 we show that isolated platelets have a low phospholipid related procoagulant activity. The PPA-B activity is not significantly increased by preincubation of the platelets with thrombin, collagen, or a combinaton of both. However, the PPA-A is increased with thrombin or collagen and more significantly by the combination of both, which is in agreement with the literature $(1,28)$. This result is to be expected because during the preincubation step no Ca-ions were present, which are required for the flip-flop reaction and thus for the development of a procoagulant platelet membrane. Only when the platelets are recalcified, i. e. on addition of the $\mathrm{FX}_{\mathrm{a}}-\mathrm{FV}_{\mathrm{a}}$ Ca-mixture, the effect of thrombin and/or collagen will develop. The increase of the PPA-A cannot be due to the effect of released factor $V$. The platelet count in the reaction mixture was $4.2 \times 10^{9} \mathrm{cell} / \mathrm{s} / \mathrm{l}$. This amount of platelets can release $0.032 \mathrm{nM}$ factor $\mathrm{V}$ (see ref. 29), which can increase the PPA-A maximally 0.01 .

Fig. 3 has shown that the PPA is proportional with the platelet count, thus it is allowed to compare different samples provided that corrections are made for the platelet count. The platelet count in this experiment maximally was $16.7 \times 10^{9}$ cells/1, so less than $0.125 \mathrm{nM}$ factor $V$ was released (see ref. 29), or the maximal effect on the PPA-A was 0.025 , or less than $2 \%$ of the calculated PPA-A.

An important simplification of the test procedure is achieved by using ammonium bicarbonate + EDTA as stop-buffer. It was shown (Fig. 4) that erythrocytes lyse in this buffer and there is no need to centrifuge the blood before the thrombin can be measured. Because the haemoglobin has a high absorption it is necessary to dilute the blood sufficiently. In practice we found that a final dilution of $60 \times$ was sufficient. Other advantages of this high dilution are (i) the determination of PPA in PRP is not disturbed by clotting of the plasma, which is some cases still occurs when the platelet count is high, (ii) the citrate in the sample is diluted to less than $0.3 \mathrm{mM}$ and only a very small effect on the prothrombinase by reducing the calcium concentration is expected, 
(iii) the ATIII is diluted so much that thrombin inactivation is slow (about $0.5 \%$ per min), which makes the thrombin determination more reliable, and (iv) coagulation reactions other than prothrombinase have become negligible, because the components which cause these reactions are diluted; in fact we found no difference in a blank with isotonic salt and with normal platelet-poor plasma.

The preliminary clinical study has shown a remarkable result. Patients with a thrombotic disease have a significant higher PPA than healthy control subjects. Because both groups are of the same age there is no need to correct for age. The mean PPA-B of the patient and control group were $1.010 \pm 0.447$ and $0.445 \pm 0.126$, respectively and the mean of the PPA-A of both groups were $0.216 \pm 0.075$ and $0.148 \pm 0.050$, respectively. These figures show that the PPA-B of the patients is significant higher than the PPA-B of the controls. The difference between the PPA-A of patients and controls is less, however, the mean of the patient group still is about $1.5 \times$ higher. These experiments are done with diluted PRP and thus the reaction mixture contains plasma factor $V$. The dilution was $60 \times$ and thus about $0.25 \mathrm{nM}$ factor $\mathrm{V}$ will be present. Table 2 shows that this amount of factor $V$ increases the PPA-A for about 0.05 . This number is negligible with the measured values.

The main goal of this article was the development of a sensitive and rapid assay to measure procoagulant phospholipids in whole blood and plasma. The described test procedure is suitable to measure in a clinic the procoagulant phospholipids in whole blood and/or plasma as was shown in the small pilot study. The factor $V_{a}$ concentration in the test mixture is $0.4 \mathrm{nM}$. For that reason the effect of platelet-released factor $V$ or plasma factor $V$ is very small, however, it has to be taken in mind that factor $V$ can affect the assay when it is present in high concentrations (see Table 2). The results obtained in the pilot study are very interesting and for that reason the study must be extended to confirm the preliminary data. These studies fall outside the scope of this article.

\section{References}

1. Bevers EM, Comfurius P, Van Rijn JLML, Hemker HC, Zwaal RFA. Generation of prothrombin-converting activity and the exposure of phosphatidylserine at the outer surface of platelets. Eur J Biochem 1982; 122: $429-36$.

2. Bevers EM, Comfurius P, Zwaal RFA. Changes in membrane phospholipid distribution during platelet activation. Biochim Biophys Acta 1983; 736 57-66.

3. Zwaal RFA, Bevers EM. Platelet phospholipid asymmetry and its significance in hemostasis. Subcell Biochem 1983; 9: 299-334.

4. Bevers EM, Rosing J, Zwaal RFA. Development of procoagulant binding sites on the platelet surface. Adv Exp Med Biol 1985; 192: 359-71.

5. Van Dieijen G, Tans G, Rosing J, Hemker HC. The role of phospholipid and factor VIII ${ }_{n}$ in the activation of bovine factor X. J Biol Chem 1981; 256: 3433-42.

6. Mertens K, Bertina RM. The contribution of $\mathrm{Ca}^{2+}$ and phospholipids to the activation of human blood-coagulation factor $\mathrm{X}$ by activated factor IX. Biochem J 1984; 223: 607-15.

7. Van Dieijen G, Van Rijn JLML, Govers-Riemslag JWP, Hemker HC, Rosing J. Assembly of the intrinsic factor $\mathrm{X}$ activating complex: Interactions between factor IX ${ }_{a}$, factor VIII and phospholipid. Thromb Haemost 1985; 53: 396-400.

8. Esmon CT, Owen WG, Jackson CM. A plausible mechanism for prothrombin activation by factor $\mathrm{X}_{2}$, factor $\mathrm{V}_{\mathrm{a}}$, phospholipid and calcium ions. $\mathrm{J}$ Biol Chem 1974; 249: 8045-57.

9. Rosing J, Tans G, Govers-Riemslag JWP, Zwaal RFA, Hemker HC. The role of phospholipids and factor $\mathrm{V}_{\mathrm{a}}$ in the prothrombinase complex. J Biol Chem 1980; 255: 274-83.
10. Van Rijn JLML, Govers-Riemslag JWP, Zwaal RFA, Rosing J. Kinetic studies of prothrombin activation: Effect of factor $\mathrm{V}_{\mathrm{a}}$ and phospholipids on the formation of the enzyme substrate complex. Biochemistry 1984; 23 : 4557-63.

11. Krishnaswamy S, Jones KC, Mann KG. Prothrombinase complex assembly. Kinetic mechanism of enzyme assembly on phospholipid vesicles, J Biol Chem 1988; 263: 3823-34.

12. Van Rijn J, Rosing J, Van Dieijen G. Activity of human blood platelets in prothrombin and in factor X activation induced by ionophore A23187. Eur J Biochem 1983; 133: 1-10.

13. Jesty J, Beltrami E, Willems G. Mathematical analysis of a proteolytic positive-feedback loop: Dependence of lag time and enzyme yields on the initial conditions and kinetic parameters. Biochemistry 1993; 32 : 6266-74.

14. Bevers EM, Tilly RH, Senden JMG, Comfurius P, Zwaal RFA. Exposure of endogenous phosphatidylserine at the outer surface of stimulated platelets is reversed by restoration of amino-phospholipid translocase activity. Biochemistry $1989 ; 28: 2382-7$.

15. Comfurius P, Senden JM, Tilly RH, Schroit AJ, Bevers EM, Zwaal RFA Loss of membrane phospholipid asymmetry in platelets and red cells may be associated with calcium-induced shedding of plasma membrane and inhibition of aminophospholipid translocase. Biochim Biophys Acta 1990; 1026 (2): $153-60$

16. Bajaj SP, Harmony JAK, Martin-Carrion M, Castellino FJ. Human plasma lipoproteins as accelerators of prothrombin activation. J Biol Chem 1976; 251: 5233-6

17. Fujikawa K, Legaz ME, Davie EW. Bovine factor $X_{1}$ and $X_{2}$ (Stuart factor). Isolation and characterization. Biochemistry 1972; 11: 4882-91.

18. Fujikawa K, Legaz ME, Davie EW. Bovine factor $X_{1}$ (Stuart factor). Mechanism of activation by a protein from Russell's viper venom. Biochemistry 1972; 11: 4892-9.

19. OwenWG, Esmon CT, Jackson CM. The conversion of prothrombin to thrombin. I. Characterization of the reaction products formed during the activation of bovine prothrombin. J Biol Chem 1974; 249: 594-605.

20. Wagenvoord RJ, Hendrix H, Soria C, Hemker HC. Localization of the inhibitory site(s) of pentosan polysulphate in blood coagulation. Thromb Haemost 1988; 60: 220-5.

21. Lindhout T, Govers-Riemslag JWP, Van de Waart P, Hemker HC, Rosing J. Factor $V_{a}$-Factor $X_{a}$ interaction. Effects of phospholipid vesicles of varying composition. Biochemistry 1982; 21: 5494-5502.

22. Comfurius $P$, Zwaal RFA. The enzymatic synthesis of phosphatidyl serine and purification by CM-cellulose column chromatography. Biochim Biophys Acta 1977; 488: 36-42.

23. Böttcher CJF, Van Gent CM, Pries C. A rapid and sensitive submicrophosphorus determination. Anal Chim Acta 1961; 24: 203-7.

24. van Rijn JLML, Govers-Riemslag JWP, Zwaal RFA, Rosing J. Kinetic studies of prothrombin activation: Effect of factor Va and phospholipids on the formation of the enzyme substrate complex. Biochemistry 1984; 23: 4557-63.

25. Workman Jr EF, Lundblad RL. The effect of monovalent cations on the catalytic activity of thrombin. Arch Biochem Biophys 1978; 185 (2): 544-8.

26. Kane WH, Lindhout MJ, Jackson CM, Majerus PW. Factor Va-dependent binding of factor Xa to human platelets. J Biol Chem 1980; 3: 1170-4.

27. Chesney CM, Pifer DD, Colman RW. Subcellular localization and secretion of factor V from human platelets. Proc Natl Acad Sci USA 1981; 78: 5180-4.

28. Rosing J, Van Rijn JLML, Bevers EM, Van Dieijen G, Comfurius P, Zwaal RFA. The role of activated human platelets in prothrombin and factor $\mathrm{X}$ activation. Blood 65: 319-32.

29. Baruch D, Hemker HC, Lindhout T. Kinetics of thrombin-induced release and activation of platelet factor V. Eur J Biochem 1986; 154: 213-8.

Received April 13, 1994 Accepted after revision June 16, 1994 